\section{Assessment of disease profiles and drug prescribing patterns of health care facilities in Edo State, Nigeria}

\author{
Ehijie F.O. Enato, ${ }^{1}$ Adebukola A. Sounyo, \\ Parvaz Madadi² \\ 1Department of Clinical Pharmacy and \\ Pharmacy Practice, Faculty of Pharmacy, \\ University of Benin, Nigeria; ${ }^{2}$ Division of \\ Clinical Pharmacology and Toxicology/ \\ Motherisk Program, Hospital for Sick \\ Children, Toronto, Canada
}

\section{Abstract}

Few studies have systematically characterized drug-prescribing patterns, particularly at the primary care level in Nigeria, a country disproportionately burdened with disease. The aim of this study was to assess the disease profiles and drug-prescribing pattern in two health care facilities in Edo State, Nigeria. The medical records of 495 patients who attended a primary or secondary health care facility in Owan-East Local Government Area of Edo State, Nigeria, between June and November 2009 were reviewed. Disease profiles and drug prescribing patterns were assessed. Data were analyzed based on the World Health Organization Anatomic Therapeutic Chemical classification system, and core drug prescribing indicators. Five hundred and twelve clinical conditions were identified. Infectious disease was most prevalent (38.3\%), followed by disorder of the alimentary tract (16.4\%). Malaria was responsible for $55.6 \%$ of the infectious diseases seen, and 21.3\% (109/512) of the total clinical conditions managed at the two health facilities during the study period. Consequently, anti-infective medications were the most frequently prescribed medicines (21.5\%), followed by vitamins (18.2\%). Use of artesunate monotherapy at both facilities (15.7\%), and chloroquine at the primary health facility (24.9\%) were common. Paracetamol (41.8\%) and non-steroidal anti-inflammatory drugs (24.9\%) were the most frequently used analgesic/antipyretic. At the primary health care facility, dipyrone was used in $21.6 \%$ of cases. The core drug prescribing use indicators showed inappropriate prescribing, indicating poly-pharmacy, overuse of antibiotics and injectio. Inappropriate drug use patterns were identified at both health care facilities, especially with regard to the use of ineffective antimalarial drugs and the use of dipyrone.

\section{Introduction}

Rational use of medicine provides patients with clinically appropriate medications at doses tailored to their individual needs, for an adequate period of time and at the lowest cost to them and their society. ${ }^{1}$ Unfortunately, irrational use of medicines is a major problem worldwide, especially in developing countries. ${ }^{1-6}$ More than half of all medicines are prescribed, dispensed or sold inappropriately and half of all patients fail to take them correctly. ${ }^{2}$ Irrational prescribing is reported to negatively impact on health and economics of individuals and the society, ${ }^{7}$ leading to wastage of scare resources and widespread health hazards. ${ }^{8,9}$ Consequently, appropriate use of drugs is recognized as one essential element in achieving quality health or medical care for patients and the community, ${ }^{8}$ and has the potential to result in $50-70 \%$ cost-efficiency in medicine expenditure. ${ }^{2}$

In order to improve medication use in health facilities, many countries and regions across the world developed their country specific essential drug list, based on the World Health Organization (WHO) model list. These essential drug lists are regularly updated to meet the needs of the local health systems. In addition, to objectively quantify drug use practices in health facilities, the WHO in 1993 developed a set of prescribing indicators. These indicators are meant to allow health planners, managers and researchers to make basic comparisons between situations in different areas or at different times, ${ }^{3,10}$ and as tools for supervision, audit and monitoring of drug use practices in health facilities. ${ }^{3,11}$

In an effort to improve medication use practices in public health institutions in Edo State, Nigeria, the State's Ministry of Health in 2009 developed its first ever essential drug list/formulary. ${ }^{12}$ Public health care practitioners in the state-owned secondary health facilities and the local government primary health care centers were expected to comply with the formulary. Though the formulary was designed based on the national formulary list, which has been in existence for years, the list is expected to address the peculiarities of local health problems in the state.

At present, little is known about medication use behaviour at the primary health care (PHC) system in Nigeria. However, under the country's national health policy, PHC is responsible for providing essential or basic health care services to the generality of the citizen, particularly in the rural areas. Given the importance of rational drug use in overall health care system, we sought to determine medication use practices at the primary care level in Nigeria. The objectives of this study,
Correspondence: Ehijie F.0. Enato, Department of Clinical Pharmacy \& Pharmacy Practice, Faculty of Pharmacy, University of Benin, Nigeria.

Tel. +234.8023597448 .

E-mail: enatoefo@uniben.edu; ehise2002@yahoo.com

Key words: antimalarials, disease profile, drug prescribing, health facilities, Nigeria.

Acknowledgements: the authors would like to thank the management and the staff of the health facilities where the study was carried out.

Conflict of interests: the authors report no conflict of interests.

Contributions: all authors participated in the study design, data analysis, manuscript drafting and reviewing; EE and AS collected the data

Received for publication: 30 July 2011 .

Revision received: 27 March 2012.

Accepted for publication: 28 July 2012.

This work is licensed under a Creative Commons Attribution NonCommercial 3.0 License (CC BYNC 3.0).

(C) Copyright E.F.O. Enato et al., 2012

Licensee PAGEPress, Italy

Journal of Public Health in Africa 2012; 3:e25

doi:10.4081/jphia.2012.e25

therefore, were to assess the disease profiles and drug prescribing patterns in two health facilities in Edo State, Nigeria.

\section{Materials and Methods}

\section{Study sites}

The study was conducted at two health care facilities located in Afuze, the administrative headquarters of Owan-East Local Government Area (LGA) of Edo State, Nigeria. The health care facilities were state government-owned general hospital, and the LGA's primary health care referral center, both providing primary health care services at the study location. The population of the LGA based on 2006 National Population and Census figure is approximated at slightly over 150,000 persons. Peasant farming and petty trading are the main occupational engagements in the LGA, except in Afuze, the administrative headquarters, where there are some civil servants.

Medical services offered at the general hospital (secondary health facility) include general practice, obstetrics, surgery, and laboratory services, which were provided by a team of 1 doctor, 7 nurses/midwives, 1 pharmacist, 1 laboratory scientist and 1 pharmacy technician. At the PHC, services include general medical 
Table 1. Disease profile of patients attending the two health care facilities.

\begin{tabular}{|c|c|c|c|c|c|}
\hline Category & System & $\begin{array}{l}\text { Clinical impression/ } \\
\text { diagnosis }\end{array}$ & $\begin{array}{l}\text { Secondary health } \\
\text { facility (n.; subtotal) }\end{array}$ & $\begin{array}{l}\text { Primary health care } \\
\text { facility (n.; subtotal) }\end{array}$ & $\begin{array}{c}\text { Overall } \\
\text { (n.; subtotal; \% of total) }\end{array}$ \\
\hline A & Alimentary & $\begin{array}{c}\text { Appendicitis } \\
\text { Ulcer } \\
\text { Intestinal obstruction } \\
\text { Gastroenteritis } \\
\text { Colitis } \\
\text { Peritonitis } \\
\text { Reflux oesophagitis } \\
\text { Diabetes mellitus } \\
\text { Dysentery } \\
\text { Cholecystitis } \\
\text { Amoebiasis } \\
\text { Haemorrhoids }\end{array}$ & $\begin{array}{c}9 ; 30 \\
12 \\
1 \\
2 \\
1 \\
1 \\
1 \\
2 \\
- \\
- \\
- \\
1\end{array}$ & $\begin{array}{l}5 ; 54 \\
26 \\
- \\
13 \\
- \\
- \\
- \\
5 \\
2 \\
2 \\
1 \\
-\end{array}$ & $\begin{array}{c}14 ; 84 ; 16.4 \% \\
38 \\
1 \\
15 \\
1 \\
1 \\
1 \\
7 \\
2 \\
2 \\
1 \\
1\end{array}$ \\
\hline B & $\begin{array}{l}\text { Blood \& blood } \\
\text { forming organs }\end{array}$ & $\begin{array}{c}\text { Anaemia } \\
\text { Septicaemia }\end{array}$ & $\begin{array}{c}17 ; 21 \\
4\end{array}$ & $\begin{array}{c}5 ; 15 \\
10\end{array}$ & $\begin{array}{c}22 ; 36 ; 7.0 \% \\
14\end{array}$ \\
\hline $\mathrm{C}$ & Cardiovascular & $\begin{array}{l}\text { Hypertension } \\
\text { Stroke } \\
\text { Shock } \\
\text { Cardiac failure } \\
\text { Hypotension }\end{array}$ & $\begin{array}{c}9 ; 15 \\
1 \\
2 \\
2 \\
1\end{array}$ & $\begin{array}{l}24 ; 26 \\
1 \\
- \\
- \\
1\end{array}$ & $\begin{array}{c}33 ; 41 ; 8.0 \% \\
1 \\
2 \\
2 \\
1\end{array}$ \\
\hline G & Genito-urinary system & $\begin{array}{c}\text { Pelvic inflammatory disease } \\
\text { Ovarian cyst } \\
\text { Urinary tract infection } \\
\text { Candidiasis } \\
\text { Hernia } \\
\text { Pyelonephritis } \\
\text { Chancroid } \\
\text { Dysmenorrhea } \\
\text { Postmenopausal syndrome } \\
\text { Prostatitis }\end{array}$ & $\begin{array}{c}3 ; 11 \\
1 \\
1 \\
2 \\
2 \\
2 \\
- \\
- \\
- \\
-\end{array}$ & $\begin{array}{c}5 ; 19 \\
- \\
9 \\
- \\
- \\
- \\
1 \\
1 \\
2 \\
1\end{array}$ & $\begin{array}{c}8 ; 30 ; 5.9 \% \\
1 \\
10 \\
2 \\
2 \\
2 \\
1 \\
1 \\
2 \\
1\end{array}$ \\
\hline I & Infection & $\begin{array}{c}\text { Malaria } \\
\text { Typhoid } \\
\text { Fever of unidentifiable cause } \\
\text { Helminthiasis } \\
\text { Herpes zoster } \\
\text { Skin infection }\end{array}$ & $\begin{array}{c}46 ; 77 \\
15 \\
13 \\
1 \\
2 \\
-\end{array}$ & $\begin{array}{l}63 ; 119 \\
44 \\
5 \\
1 \\
- \\
6\end{array}$ & $\begin{array}{c}109 ; 196 ; 38.3 \% \\
59 \\
18 \\
2 \\
2 \\
6\end{array}$ \\
\hline M & Musculoskeletal & $\begin{array}{c}\text { Osteoarthritis } \\
\text { Rheumatoid arthritis } \\
\text { Body pain }\end{array}$ & $\begin{array}{c}2 ; 8 \\
4 \\
2\end{array}$ & $\begin{array}{l}3 ; 19 \\
13 \\
3\end{array}$ & $\begin{array}{c}5 ; 27 ; 5.3 \% \\
17 \\
5\end{array}$ \\
\hline N & Nervous & $\begin{array}{c}\text { Meningitis } \\
\text { Insomnia } \\
\text { Anxiety } \\
\text { Trauma } \\
\text { Epilepsy } \\
\text { Schizoaffective disorder } \\
\text { Migraine headache } \\
\text { Cranial nerve damage }\end{array}$ & $\begin{array}{l}3 ; 11 \\
1 \\
1 \\
4 \\
2 \\
- \\
- \\
-\end{array}$ & $\begin{array}{c}-; 38 \\
1 \\
2 \\
32 \\
- \\
1 \\
1 \\
1\end{array}$ & $\begin{array}{c}3 ; 49 ; 9.6 \% \\
2 \\
3 \\
36 \\
2 \\
1 \\
1 \\
1\end{array}$ \\
\hline $\mathrm{R}$ & Respiratory & $\begin{array}{c}\text { Asthma } \\
\text { Pneumonia } \\
\text { Respiratory tract infection } \\
\text { Pulmonary Koch disease }\end{array}$ & $\begin{array}{l}1 ; 13 \\
2 \\
6 \\
2\end{array}$ & $\begin{array}{l}1 ; 28 \\
8 \\
15 \\
2\end{array}$ & $\begin{array}{c}2 ; 41 ; 8.0 \% \\
10 \\
21 \\
4\end{array}$ \\
\hline $\mathrm{S}$ & Sensory & $\begin{array}{c}\text { Retinopathy } \\
\text { Otitis media } \\
\text { Corneal ulceration }\end{array}$ & $\begin{array}{l}1 \\
1 \\
-\end{array}$ & $\begin{array}{l}1 \\
- \\
1\end{array}$ & $\begin{array}{l}2 \\
1 \\
1\end{array}$ \\
\hline V & Various & $\begin{array}{c}\text { Allergy } \\
\text { Vitiligo } \\
\text { Dermitis } \\
\text { Cellulitis }\end{array}$ & $\begin{array}{l}-; 0 \\
- \\
- \\
-\end{array}$ & $\begin{array}{c}5 ; 8 \\
1 \\
1 \\
1\end{array}$ & $\begin{array}{c}5 ; 8 ; 1.6 \% \\
1 \\
1 \\
1\end{array}$ \\
\hline Total & & & 186 & 326 & $512 ; 100.1^{*}$ \\
\hline
\end{tabular}

*Slightly more than 100\% due to approximation to the nearest figure. 
care, obstetrics and gynecological care, laboratory services, and HIV/AIDS care. These services were provided by a team of 2 doctors, 6 nurses/midwives, 4 laboratory scientists, 3 pharmacy technicians, and 4 community health workers. At both health care facilities, the medical officers and nurses/midwives were primarily responsible for drug prescribing. On the average, about 12 patients/day and 20 patients/day were attended to at the general hospital and the PHC, respectively. In addition, the drugs prescribed were dispensed at the hospitals' pharmacies, when available; otherwise patients were advised to purchase their medications from the private retail sector. Furthermore, patients pay out-of-pocket for their medical expenses including purchase of medication, as the nation health assurance scheme is yet to be fully implemented.

\section{Data collection process}

The data collection form was developed from the WHO's health facility drug use indicator. ${ }^{3}$ Data for six months period (June to November, 2009) were collected. Prior to this, ethical approval was obtained from the University of Benin Ethical Review Committee, and the health facilities gave administrative approvals.

Sampling procedure included the following. First, the total number of encounters over the 6 month period was estimated by using the average number of encounters per day, giving 2196 and 3660 for general hospital and PHC, respectively. Thereafter, by projecting minimum sample sizes of 150 and 300 clinical encounters from the respective health facility, we calculated the sampling intervals for both health care facilities. ${ }^{3}$ Thereafter, every other $15^{\text {th }}$ or $22^{\text {nd }}$ clinical encounter was selected from the secondary or primary health care facility, respectively. In few cases were a selected clinical encounter did not have the complete information, it was discarded and the next encounter selected, until the samples sizes were obtained. It is important to mention that the recommendation is that when comparing drug prescribing pattern of health facilities, a minimum sample size of 100 patient encounters is sufficient to give a $95 \% \mathrm{CI}$ of within $10 \%$ for the individual result. 3,10 Information on prescribing pattern was abstracted from the patient's medical record, including age, sex, diagnosis; name and dosage form of the drug prescribed and the information were recorded on the data abstraction form.

\section{Data analysis}

The abstracted data were entered in Excel spreadsheet and sorted. Percentage frequencies of the various medical disorders and drug utilization were determined. Thereafter, the prescribing indicators were calculated based on the WHO guidelines, ${ }^{3}$ including: average number of drugs per encounter, the percentage of drugs prescribed by generic name, the percentage of encounters with an antibiotic or injection prescribed, and percentage of drugs prescribed from the essential drug list. In addition, the calculated core drug prescribing indicators were compared with population reference values earlier derived for the locality..$^{13}$ Furthermore, the prescribed drugs were classified based on Anatomical, Therapeutic and Chemical (ATC) classification of pharmaceuticals. In addition, because we were particularly interested in understanding the drug use patterns in children five years and below, we further categorized the patients into $\leq 5$ and $>5$ years old. It is noteworthy that malaria is a major public health problem among children five years and below.

Table 2. Profile of medications prescribed at the two health care facilities.

\begin{tabular}{|c|c|c|c|c|}
\hline ATC code & Drug type & $\begin{array}{l}\text { Secondary health facility } \\
\text { (n-; subtotal) }\end{array}$ & $\begin{array}{l}\text { Primary health care facility } \\
\text { (n.; subtotal) }\end{array}$ & $\begin{array}{c}\text { Overall } \\
\text { (n.; subtotal; \% of total) }\end{array}$ \\
\hline A & $\begin{array}{l}\text { Vitamin } \\
\text { Anti-ulcer } \\
\text { Anti-diabetics } \\
\text { Mineral supplement } \\
\text { Anti-diarrhoeal } \\
\text { Anti-spasmodic } \\
\text { Anti-emetics }\end{array}$ & $\begin{array}{c}110 ; 152 \\
24 \\
4 \\
2 \\
1 \\
9 \\
2\end{array}$ & $\begin{array}{c}242 ; 365 \\
58 \\
9 \\
3 \\
11 \\
30 \\
12\end{array}$ & $\begin{array}{c}352 ; 517 ; 18.2 \\
82 \\
13 \\
5 \\
12 \\
39 \\
14\end{array}$ \\
\hline B & $\begin{array}{l}\text { Anti-anaemic } \\
\text { Blood substitutes and perfusion }\end{array}$ & $\begin{array}{c}75 ; 141 \\
66\end{array}$ & $\begin{array}{c}62 ; 164 \\
102\end{array}$ & $\begin{array}{l}137 ; 305 ; 10.8 \\
\quad 168\end{array}$ \\
\hline $\mathrm{C}$ & $\begin{array}{l}\text { Anti-hypertensive } \\
\text { Diuretics } \\
\text { Vasoprotectives }\end{array}$ & $\begin{array}{c}36 ; 56 \\
20 \\
-\end{array}$ & $\begin{array}{c}64 ; 66 \\
- \\
2\end{array}$ & $\begin{array}{l}100 ; 122 ; 4.3 \\
20 \\
2\end{array}$ \\
\hline D & $\begin{array}{l}\text { Anti-fungal } \\
\text { Anti-pruritis including anti-histamine } \\
\text { Corticosteroids } \\
\text { Antiseptics and disinfectants }\end{array}$ & $\begin{array}{c}4 ; 68 \\
41 \\
22 \\
1\end{array}$ & $\begin{array}{l}13 ; 146 \\
72 \\
57 \\
4\end{array}$ & $\begin{array}{c}17 ; 214 ; 7.5 \\
113 \\
79 \\
5\end{array}$ \\
\hline G & Other gynaecologicals & $2 ; 2$ & $1 ; 1$ & $3 ; 3 ; 0.1$ \\
\hline $\mathrm{J}$ & Anti-infectives for systemic use & $233 ; 233$ & $376 ; 376$ & $609 ; 609 ; 21.5$ \\
\hline $\mathrm{L}$ & Immunostimulants & $6 ; 6$ & $27 ; 27$ & $33 ; 33 ; 1.2$ \\
\hline M & $\begin{array}{l}\text { Anti-inflammatory and anti-rheumatic } \\
\text { Topical products }\end{array}$ & $\begin{array}{c}32 ; 34 \\
2\end{array}$ & $\begin{array}{c}152 ; 175 \\
23\end{array}$ & $\begin{array}{l}184 ; 209 ; 7.4 \\
25\end{array}$ \\
\hline N & $\begin{array}{l}\text { Analgesics } \\
\text { Anti-epileptics } \\
\text { Psycholeptics }\end{array}$ & $\begin{array}{l}129 ; 183 \\
2 \\
52\end{array}$ & $\begin{array}{c}158 ; 203 \\
- \\
45\end{array}$ & $\begin{array}{c}285 ; 386 ; 13.6 \\
2 \\
97\end{array}$ \\
\hline$P$ & $\begin{array}{l}\text { Anti-protozoals } \\
\text { Anti-helmintics }\end{array}$ & $\begin{array}{l}130 ; 146 \\
16\end{array}$ & $\begin{array}{l}253 ; 275 \\
22\end{array}$ & $\begin{array}{l}383 ; 421 ; 14.8 \\
38\end{array}$ \\
\hline $\mathrm{R}$ & Nasal preparations & $6 ; 6$ & $10 ; 10$ & $16 ; 16 ; 0.6$ \\
\hline S & Opthalmologicals & - & $1 ; 1$ & $1 ; 1 ; 0.04$ \\
\hline Total & & 1027 & 1809 & $2836 ; 100.0$ \\
\hline
\end{tabular}

ATC, Anatomical, Therapeutic and Chemical classification of pharmaceuticals. 


\section{Results}

A sample of 495 medical records of patients who attended the two health facilities during the study period (June to November, 2009) was assessed for relevant information. Overall, 512 clinical conditions were attended to at the two hospitals of which $63.7 \%$ were reported in the primary health care facility. The contributions of the various clinical conditions to the overall dis- ease burden, according to the WHO ATC system of the World Health Organization, are as shown in Table 1. Infectious diseases were the most frequently reported clinical condition, resulting in $38.3 \%(196 / 512)$ of the total cases seen at the two health care facilities. This was followed by the disorders of the alimentary system (16.4\%). Malaria was responsible for $55.6 \%$ of the infectious diseases seen, and $21.3 \%$ (109/512) of the total clinical conditions managed at the two health facilities during the study period.
The medication use profile (Table 2) indicates that anti-infective (21.5\%) were the most frequently prescribed medicines, followed by vitamins (18.2\%). The distribution of four classes of medications, analgesic/antipyretic, antimalarials, antibiotics, and vitamins for the two age categories (five years and younger and over five years old) at the two health care facilities is shown in Table 3 . As expected, there was a significant difference in the use of these medications between the two age groups.

Table 3. Classes of medication prescribed by the health facilities.

$\begin{array}{ccc}\text { Secondary health facility }(\mathrm{n}=180) & \text { Primary health facility }(\mathrm{n}=315) \\ \text { Class of medication } \quad \text { Total } \leq 5 \text { year old }>5 \text { year old Total } \leq 5 \text { year old }>5 \text { year old } \quad \text { Total } \leq 5 \text { year old }>5 \text { year }\end{array}$

\begin{tabular}{|c|c|c|c|c|c|c|c|c|c|}
\hline Analgesic/antipyretic & 154 & $33(21.4)$ & $121(78.6)$ & 291 & $44(15.1)$ & $247(84.9)$ & 445 & $77(17.3)$ & $368(82.7)$ \\
\hline Antimalarials & 130 & $44(33.8)$ & $86(66.2)$ & 253 & $66(26.1)$ & $187(73.9)$ & 383 & $110(28.7)$ & $273(71.3)$ \\
\hline Antibiotics & 233 & $39(16.7)$ & $194(83.3)$ & 376 & $76(20.2)$ & $300(79.8)$ & 609 & $115(18.9)$ & 494 \\
\hline Vitamins & 110 & $21(19.1)$ & $89(80.9)$ & 242 & $49(20.2)$ & $193(79.8)$ & 352 & $70(19.9)$ & $282(80$ \\
\hline
\end{tabular}

${ }^{*} \chi^{2}$ test $=19.40$; degree of freedom $=3 ; \mathrm{P}<0.05, \leq 5 \mathrm{yr}$ old and $>5 \mathrm{yr}$ old (overall) compared.

Table 4. Prescribing profiles for antimalarials, analgesics, and antibiotics.

\begin{tabular}{|c|c|c|c|c|}
\hline Drug category & Specific drug type & $\begin{array}{l}\text { Overall } \\
\text { n. }(\%)\end{array}$ & $\begin{array}{l}\text { Secondary health care facility } \\
\text { n. (\%) }\end{array}$ & $\begin{array}{c}\text { Primary health care facility } \\
\text { n. }(\%)\end{array}$ \\
\hline $\begin{array}{l}\text { Analgesic/antipyretic } \\
\text { Total }\end{array}$ & $\begin{array}{l}\text { Dipyrone } \\
\text { Paracetamol } \\
\text { NSAID }^{\mathrm{a}} \\
\text { Other }^{\mathrm{b}}\end{array}$ & $\begin{array}{l}63(14.2) \\
186(41.8) \\
111(24.9) \\
85(19.1) \\
445\end{array}$ & $\begin{array}{c}0(0) \\
104(67.5) \\
25(16.2) \\
25(16.2) \\
154\end{array}$ & $\begin{array}{l}63(21.6) \\
82(28.2) \\
86(29.6) \\
60(20.6) \\
291\end{array}$ \\
\hline $\begin{array}{l}\text { Antimalarial } \\
\text { Total }\end{array}$ & $\begin{array}{l}\text { Artesunate monotherapy } \\
\text { ACTc } \\
\text { Chloroquine } \\
\text { Quinine } \\
\text { Sulphadoxine/pyrimethamine } \\
\text { Amodiaquine monotherapy } \\
\text { Other }^{\mathrm{d}}\end{array}$ & $\begin{array}{c}60(15.7) \\
56(14.6) \\
63(16.4) \\
106(27.7) \\
62(16.2) \\
34(8.9) \\
2(0.5) \\
383\end{array}$ & $\begin{array}{c}35(26.9) \\
50(38.5) \\
0(0) \\
32(24.6) \\
12(9.2) \\
0(0) \\
1(0.8) \\
130\end{array}$ & $\begin{array}{c}25(9.9) \\
6(2.4) \\
63(24.9) \\
74(29.2) \\
50(19.8) \\
34(13.4) \\
1(0.4) \\
253\end{array}$ \\
\hline Antibiotics & $\begin{array}{l}\text { Penicillins } \\
\text { Cephalosporins } \\
\text { Gentamycin } \\
\text { Co-trimoxazole } \\
\text { Metronidazole } \\
\text { Other }\end{array}$ & $\begin{array}{l}148(24.3) \\
200(32.8) \\
85(14.0) \\
21(3.4) \\
116(19.0) \\
39(6.4) \\
609\end{array}$ & $\begin{array}{c}102(43.8) \\
31(13.3) \\
25(10.7) \\
4(1.7) \\
56(24.0) \\
15(6.4) \\
233\end{array}$ & $\begin{array}{c}46(12.2) \\
169(44.9) \\
60(16.0) \\
17(4.5) \\
60(16) \\
24(6.4) \\
376\end{array}$ \\
\hline
\end{tabular}

${ }^{a}$ NSAID, non-steroidal anti-inflammatory drugs; ${ }^{b}$ Other $=$ Norgesic ${ }^{\circledR}$ (aspririn+caffeine+orphenadrine citrate), tramadol and pentazocine; ${ }^{\mathrm{C} A C T}$, Arthemisinine-based combination therapy; ${ }^{\mathrm{d}}$ Other=Halofantrine and proguanil; ${ }^{\text {eOther}=e r y t h r o m y c i n, ~ n e o m y c i n, ~ c h l o r a m p h e n i c o l, ~ a m o x y c i l l i n / c l a v u l a n i c ~ a c i d, ~ n i t r o f u r a n t o i n . ~}$

Table 5. Drug use based on World Health Organization drug use indicators.

\begin{tabular}{|c|c|c|c|c|c|c|c|}
\hline \multirow[b]{2}{*}{ Drug use indicator } & \multicolumn{3}{|c|}{ Secondary health facility $(\mathrm{n}=180)$} & \multicolumn{3}{|c|}{ Primary health facility (n=315) } & \multirow[t]{2}{*}{ Local ref. value ${ }^{2}$} \\
\hline & Total & $\leq 5$ year old & $>5$ year old & Total & $\leq 5$ year old & $>5$ year old & \\
\hline Average no. of drugs/encounter & 5.7 & 5.8 & 5.7 & 5.74 & 5.7 & 5.7 & $1.6-1.8$ \\
\hline$\%$ of drugs prescribed by generic names & 47.7 & 47.3 & 47.8 & 52.0 & 47.4 & 53.0 & 100 \\
\hline \% of encounter with antibiotic prescribed & 72.2 & 73.7 & 71.8 & 70.8 & 86.2 & 67.3 & $20-26.8$ \\
\hline$\%$ of encounter with injection prescribed & 70.6 & 71.1 & 70.4 & 73.6 & 77.6 & 72.8 & 13.4-24.1 \\
\hline$\%$ of prescribed drugs from EDL ${ }^{b}$ & 63.9 & 63.1 & 64 & 59.8 & 60.4 & 59.6 & 100 \\
\hline
\end{tabular}

asah et al., 200213; bEDL, essential drug list of Edo State Ministry of Health, Nigeria. 
Table 4 depicts the specific drug type associated with each medication class. Of the analgesics/antipyretics, paracetamol was most commonly prescribed (41.8\%), followed by non-steroidal anti-inflammatory drugs (24.9\%). Dipyrone was used in $21.6 \%$ of cases of those who received analgesic medication at primary health care centre.

Among the antimalarial drugs, quinine (27.7\%), sulphadoxine/pyrimethamine (16.2\%), and artesunate monotherapy (15.7\%) were mostly used. Chloroquine was prescribed in $24.9 \%$ of patients receiving antimalarial drugs in primary health care center. Penicillin (43.8\%) and cephalosporin (44.9\%) were the most frequently prescribed antibiotics at the secondary and primary health care facilities, respectively (Table 4). The pattern of drug prescribing according to the WHO core drug use indicators is shown in Table 5. In all indicators assessed, the values obtained negatively deviated from locally derived reference values. ${ }^{13}$

\section{Discussion}

Essential medicines are those medicines that satisfy the priority health care needs of the population. Any selection of essential medicines therefore needs to take into consideration the public health relevance, the best available clinical evidence of efficacy and safety as well as assessment of comparative cost-effectiveness. ${ }^{8}$ In addition, the concept of essential medicines can only reduce suffering and improve health if medicines are of good quality, safe, available, affordable and properly used by both the prescribers and the consumers. ${ }^{7,14,15}$ We undertook this study to assess the disease profiles and drug prescribing patterns at the primary care level in Nigeria in order to identify priority areas for focused action, particularly with regard to rational medication use. Our study identified infectious diseases as the most prevalent health problem presented at the health care facilities, especially malaria which accounted for over half of all reported infectious illnesses. This was followed by disorders of the alimentary system. This finding is similar to previous reports in the locality, where malaria was found to be the most prevalent clinical encounter. ${ }^{13}$ Malaria is a major public health problem in the country, resulting in high morbidity and mortality, particularly among pregnant women and young children. ${ }^{16}$ Though there have been several national and international efforts at reducing the intolerable burden of the disease, the impact of these efforts are yet to be fully seen at the community. Similarly, through community-based household survey, we identified malaria and related symptoms as the most prevalent illness in the locality. ${ }^{17}$ Consequently, antimalarial drugs, analgesic/antipyretic, and vitamins were the most commonly prescribed medications. A more detailed investigation into the types of antimalarial drug prescribed revealed that artesunate monotherapy was readily prescribed by both health care facilities, and chloroquine by the primary health care center. This observation is a clear indication that the health care providers were yet to adhere to the current malaria treatment guideline in the country. The Nigerian antimalarial treatment policy of 2004 recommends artemisinin-based combination therapy (ACT) for the treatment of acute uncomplicated malaria ${ }^{16}$ in children and adult non-pregnant women, while oral quinine is recommended for pregnant women. Though ACTs are proven to be safe and effective in the management of malaria in endemic countries, ${ }^{18}$ ability to pay for these life saving medications has always been a major challenge. The average cost of a full course of ACT in Nigeria, at the time of the study was about $\$ 5$ (N750), which is beyond the expenditure of most households in the locality with a median monthly income of less than $\$ 70$. Equally disturbing is the high use of artemisinin monotherapy by these health facilities, despite its ban by WHO because it is likely to accelerate the development of artemsinin resistance. ${ }^{19,20}$ In addition, we also found that dipyrone was still in use at the primary health care facility. Dipyrone is noted for its serious adverse effect of agranulocytosis among users, prompting is its ban from clinical use in several countries, ${ }^{21}$ including Nigeria.

Furthermore, assessment of the WHO core drug prescribing indicators showed inappropriate prescribing, particularly when compared with the local reference values, ${ }^{13}$ and previous studies in some other health care facilities in the locality. 5,13,22 This finding indicates a high tendency for poly-pharmacy, overuse of antibiotics and injection, and non-compliance with the principles of essential drug program. The reason for this observation could not be ascertained from the data available to us in this study; however, this warrants further investigation.

\section{Conclusions}

We identified infectious diseases (mostly malaria) and disorders of the alimentary tract as the most common clinical encounters at the health facilities. Consequently, antimalarials, vitamins, analgesic/antipyretics were mostly prescribed. However, the quality of antimalarial prescribing was found to be sub-optimal. Despite the national antimalarial treatment policy, which recommends artemisinin-based combination therapy for acute uncomplicated malaria, use of artesunate monotherapy and chloroquine was common. Furthermore, prescribing pattern indicated poly-pharmacy, overuse of antibiotics and injection.

\section{References}

1. World Health Organization. The rational use of drugs. reports of the conference of experts. Geneva: World Health Organization; 1985.

2. World Health Organization. WHO medicine strategy 2008-2013. Geneva: World Health Organization; 2008.

3. World Health Organization. How to investigate drug use in health facilities. Selected drug use indicators. WHO/DAP/ 93.1. Geneva: World Health Organization; 1993.

4. Enato EFO, Aghomo OE, Oparah CA, et al. Drug utilization in a Nigerian rural community. JMBR 2003;2:15-22.

5. Isah A0, Ohaju-Obodo J, Isah EC, Ozemoya 0 . Drug use profile in a Nigerian city hospital. Pharmacoepidemiol Drug Saf 1997;6:319-24.

6. Ohaju-Obodo JO, Isah AO, Mabadeje AFB. Prescribing pattern of clinicians in private health instituitions in Edo and Delta States of Nigeria. Nig Qt J Hosp Med 1998; 8:91-4.

7. Bashrahil KA. Indicators for rational drug use and health services in Hadramout, Yemen. Eastern Mediterr H J 2010;16:151-5.

8. World Health Organization. WHO medicines strategy 2004-2007: countries at the core. WHO/EDM/2004.2. Geneva: World Health Organization; 2004.

9. Ghimire S, Nepal S, Bhandari S, et al. A prospective surveillance of drug prescribing and dispensing in a teaching hospital in Western Nepal. J Pak Med Assoc 2009;59:726-31.

10. Hogerzeil HV, Ross-Degnan BD, Laing RO, et al. Field tests for rational drug use in twelve developing countries. Lancet 1993;342:1408-10.

11. Baker R. Audit in practice: improve care. Br Med J 1992;304:1455-6.

12. Edo State Essential drug list. Benin City, Edo State, Nigeria: Edo State Ministry of Health; 2009.

13. Isah A0, Laing J, Quick AFB, et al. The development of reference values for the WHO health facility core prescribing indicators. West Afr J Pharmacol Drug Res 2002;18:6-11.

14. Sachs L, Tomson G. Medicines and culture-a double perspective on drug utilization in developing country. Soc Sci Med 
1992;34:307-15.

15. Hogerzeil HV. Promoting rational prescribing: an international perspective. Br J Clin Pharmacol 1995;39:1-6.

16. Federal Ministry of Health. National malaria control policy for Nigeria. Lagos, Nigeria: National Malaria and Vector Control Division; 2004.

17. Enato EFO, Sounyo AA, Einarson T. Medication utilization and illness management study in Nigeria. Ann Pharmacother 2011;45:294-30.

18. World Health Organization. Antimalarial drug combination therapy. Report of the World Health Organization Technical Consultation. Geneva: World Health Organization; 2001.

19. Rehwagen C. WHO ultimatum on artemisinin monotherapy is showing results. BMJ 2006;332:1176.

20. Sabot OJ, Mwita A, Cohen JM, et al. Piloting the global subsidy: the impact of subsidized artemisinin-based combination therapies distributed through private drug shops in rural Tanzania. PloS One 2009;4:e6857.
21. Roberts LJ, Morrow JD. Analgesicantipyretic and anti-inflammatory agents and drugs employed in the treatment of gout. In: Hardman JG, Limbird LE, Gilman AG, eds. Goodman and Gilman's, The pharmacological basis of therapeutics (11th ed). New York: McGraw-Hill Medical Publishing Division; 2001. pp 687-731.

22. Enwere 00, Falade CO, Slako BL. Drug prescribing pattern at the medical outpatient clinic of a tertiary hospital in southwestern Nigeria. Pharmacoepidemiol Drug Saf 2007;16:1244-9. 